\title{
KORELASI ANTARA HUKUM ADAT DENGAN ALIRAN POSITIVISME HUKUM DI INDONESIA
}

\author{
Afrinald Rizhan \\ Program Studi Ilmu Hukum, Fakultas Ilmu Sosial, Universitas Islam Kuantan Singingi \\ afrinaldrizhan@gmail.com
}

\begin{abstract}
The Republic of Indonesia, which is a recht state, we recognize the existence of various laws, both written laws are regulations relic of the Dutch East Indies, as well as unwritten law which is customary law that diverse. It's just the problems that arise at this time, when we see that the trend of Indonesia that follows the flow of Positivism will affect the customary law which is an unwritten law that is recognized and developed within the indigenous peoples of Indonesia.
\end{abstract}

Key words: recht state, unwritten law, and legal positivism

\begin{abstract}
Abstrak
Negara Republik Indonesia, yang merupakan negara hukum, kita mengenal adanya bermacam-macam hukum, baik hukum tertulis yang merupakan peraturan-peraturan peninggalan zaman Hindia Belanda, maupun hukum tidak tertulis yang merupakan hukum adat yang beraneka ragam. Hanya saja permasalahan yang timbul saat ini, ketika kita melihat bahwa kecenderungan Indonesia yang mengikuti aliran Positivisme akan berpengaruh pada hukum adat yang merupakan hukum tidak tertulis yang diakui dan berkembang di lingkungan masyarakat adat Indonesia
\end{abstract}

Kata Kunci: negara hukum, hukum adat, dan positivisme hokum

\section{A. Pendahuluan}

Indonesia sebagai negara yang beradab yang diproklamasikan pada tanggal 17 Agustus 1945 yang menegaskan dirinya sebagai negara hukum. Dalam Pasal 1 ayat (3) Undang-Undang Dasar 1945 disebutkan bahwa Indonesia adalah Negara Hukum. Sebagai suatu negara hukum, sudah selayaknya prinsip-prinsip dari suatu negara hukum harus dihormati dan dijunjung tinggi. Salah satunya adalah setiap tindakan pemerintah selalu harus didasarkan pada asas legalitas atau harus berdasarkan peraturan perundang-undangan yang berlaku. Artinya tindakan hukum pemerintah dalam melaksanakan ketentuan-ketentuan yang berlaku atau dalam rangka mengatur dan melayani kepentingan umum yang dikristalisasikan 
dalam ketentuan undang-undang yang bersangkutan. Ketentuan undang-undang ini melahirkan kewenangan tertentu bagi pemerintah untuk melakukan tindakan hukum tertentu. ${ }^{1}$

Seiring dengan pilar utama negara hukum yaitu asas legalitas (legaliteitsbeginsel atau het beginsel van wet matigheid van bestuur), maka berdasarkan prinsip ini bersifat tersirat bahwa wewenang pemerintahan berasal dari peraturan perundang-undangan, artinya sumber wewenang bagi pemerintah adalah peraturan perundang-undangan. ${ }^{2}$

Dalam Undang-Undang Dasar 1945, terlihat bahwa Negara Republik Indonesia yang berdiri pada tanggal 17 Agustus 1945 adalah negara yang berdasar atas hukum dalam arti negara pengurus (Verzorgingsstaat). Hal ini tertulis dalam Pembukaan UUD 1945 alinea ke-4 yang berbunyi sebagai berikut :

“..... untuk membentuk suatu pemerintahan negara Indonesia yang melindungi segenap bangsa Indonesia dan seluruh tumpah darah Indonesia dan untuk memajukan kesejahteraan umum, mencerdaskan kehidupan bangsa, dan ikut melaksanakan ketertiban dunia yang berdasarkan kemerdekaan, perdamaian abadi, dan keadilan sosial.....,

Dengan diembannya tugas negara dalam menyelenggarakan kesejahteraan umum tersebut, maka menjadi pentinglah arti pembentukan peraturan-peraturan negara kita, karena campur tangan negara dalam mengurusi kesejahteraan rakyat dalam bidang hukum, sosial, politik, ekonomi, budaya, lingkungan hidup, serta pertahanan dan keamanan yang diselenggarakan dengan pembentukan peraturan-peraturan negara tak mungkin lagi dihindarkan. ${ }^{4}$ Mengingat hal ini juga merupakan cita-cita bangsa dan Negara Indonesia yang terangkum dalam konstitusi.

Fungsi pembentukan peraturan perundang-undangan itu semakin terasa diperlukan kehadirannya karena di dalam negara yang berdasar atas hukum modern (verzorgingsstaat), tujuan utama pembentukan undang-undang bukan lagi menciptakan kodifikasi bagi normanorma dan nilai-nilai kehidupan yang sudah mengendap dalam masyarakat, melainkan menciptakan modifikasi atau perubahan dalam masyarakat. ${ }^{5}$ Hal ini tentunya akan membantu perkembangan hukum yang ada di lingkungan masyarakat Indonesia, melihat selama ini kita hanya meniru peraturan-peraturan yang telah di warisi oleh Penjajah, tanpa peduli apakah

\footnotetext{
${ }^{1}$ Ridwan HR, Hukum Administrasi Negara, PT. RajaGrafindo Persada, Jakarta, 2006, hal. 123. ${ }^{2}$ Ibid, hal. 103 .

${ }^{3}$ Indonesia, Undang-Undang Dasar 1945, Pembukaan.

${ }^{4}$ Maria Farida Indrati Soeprapto, Ilmu Perundang-Undangan, Kanisius, Yogyakarta: 1998, Hal. 1

${ }^{5}$ T. Koopmans, "De rol van de wetgever", dalam Honderd Jaar rechtsleven, Zwole, Tjeenk Willink, 1972 , Hal. 223, dalam Maria Farida Indrati Soeprapto, Ibid.
} 
peraturan itu sesuai atau tidak dengan adat istiadat yang tumbuh dan berkembang di lingkungan masyarakat adat di Indonesia.

Dengan adanya pengutamaan pada pembentukan undang-undang melalui cara modifikasi, maka diharapkan bahwa suatu Undang-Undang itu tidak lagi berada di belakang dan kadang-kadang terasa ketinggalan, tetapi dapat berada di depan, dan tetap berlaku sesuai dengan perkembangan masyarakat. I.C Van Der Vlies berpendapat bahwa Undang-Undang modifikasi adalah Undang-Undang yang bertujuan mengubah pendapat hukum yang berlaku, dan peraturan perundang-undangan yang mengubah hubungan-hubungan sosial. ${ }^{6}$

Hukum ialah hukum yang berlaku dalam sebuah Negara, hukum semacam ini disebut hukum positif. Asal mula hukum ini ialah penetapan oleh pimpinan yang sah dalam Negara. ${ }^{7}$ Hukum sebagai kategori moral serupa dengan keadilan. Kata keadilan juga digunakan dalam pengertian hukum, dari segi kecocokan dengan hukum positif, terutama kecocokan dengan Undang-Undang. ${ }^{8}$ Karena hukum mengikat semua orang, maka keadilan hukum mesti dipahami dalam pengertian kesamaan. ${ }^{9}$ Hukum positif tidak berusaha dipisahkan dengan jelas dari keadilan, dan semakin baik usaha pembuat undang-undang agar hukum tersebut juga dianggap adil bagaimana pun juga, semakin banyak dukungan terhadap bias ideologis yang merupakan karakteristik teori hukum alam klasik, konservatif. ${ }^{10}$

Hukum nasional Indonesia dewasa ini masih dalam proses pembentukan. Beberapa perundang-undangan nasional (dalam arti perundang-undangan nasional yang dibentuk setelah Indonesia) memang telah ada, namun apakah perundang-undangan itu telah sesuai dengan Cita Hukum Nasional, kita perlu menelitinya dengan cermat. ${ }^{11}$ Melihat betapa banyaknya Peraturan-peraturan yang di buat, akan tetapi tidak di terapkan sesuai dengan tujuan dan fungsi dari peraturan tersebut, juga tumpang tindih dengan kepentingankepentingan politik semata yang merugikan beberapa kalangan tertentu.

Oleh karena dalam perkembangannya kita tidak dapat selalu mengandalkan lagi terbentuknya peraturan-peraturan negara dengan kodifikasi, yang memerlukan waktu yang lama, maka dalam memenuhi kebutuhan kita membentuk Hukum Nasional tidak dapat lain

\footnotetext{
${ }^{6}$ I.C Van Der Vlies, Handbook Wetgeving, Zwole, Tjeenk Willink, 1987, Hal. 9, dalam Maria Farida Indrati Soeprapto, Ibid.

${ }^{7}$ Theo Huijbers, Filsafat Hukum Dalam Lintasan Sejarah, Kanisius, Yogyakarta: 1982, Hal. 273

${ }^{8}$ Hans Kelsen, Pengantar Teori Hukum, Nusamedia, Bandung: 2009, Hal. 48

${ }^{9}$ Satjipto Rahardjo, Teori Hukum, Genta Publishing, Yogyakarta: 2010, Hal.45

${ }^{10}$ Hans Kelsen, op. cit., Hal. 51

11 A. Hamid S. Attamimi. Fungsi Ilmu Perundang-Undangan dalam Pembentukan Hukum Nasional, makalah disampaikan pada ceramah ilmiah di fakultas Hukum Universitas Islam Assyafiah, Jakarta 17 Maret 1989, Hal. 5
} 
kecuali dengan cara membentuk hukum yang tertulis, yang pembentukannya relatif lebih cepat. Apabila demikian, pengembangan Ilmu Perundang-Undangan terasa semakin perlu untuk membentuk Hukum Nasional, karena Hukum Nasional yang dicita-citakan akan terdiri dari hukum tertulis dan tidak tertulis. Selain itu, pembentukan hukum tertulis itu dirasakan sangat perlu bagi perkembangan masyarakat dan negara saat ini. ${ }^{12}$

Hukum tertulis, selain merupakan wahana bagi hukum baru yang dibentuk setelah Indonesia merdeka dalam rangka memenuhi kebutuhan kehidupan kenegaraan, kebangsaan, dan kemasyarakatan yang senantiasa berkembang juga perlu untuk "menjembatani" antar lingkup laku aneka adat dan hukum tidak tertulis lainnya, atau untuk mengatasi kebutuhan kepastian hukum tidak tertulis dalam hal pihak-pihak mengkehendakinya. ${ }^{13}$ Indonesia juga merupakan sebuah negara yang cenderung mengikuti aliran Positivisme, yakni aliran yang mengidentikkan hukum dengan Undang-Undang. Tidak ada hukum di luar Undang-Undang, satu-satunya sumber hukum adalah Undang-Undang. Di Jerman pandangan ini banyak dianut dan dipertahankan oleh Paul Laband, Jellinek, Rudolf von Jhering, Hans Nawiasky, Hans Kelsen dan lain-lain. ${ }^{14}$

Di Indonesia sendiri pengaruh pemikiran legisme itu sangat jelas dapat dibaca pada Pasal 15 Algemene Bepalingen van Wetgeving yang antara lain berbunyi (dalam bahasa Indonesia) :

Terkecuali penyimpangan-penyimpangan yang ditentukan bagi orang-orang Indonesia dan mereka yang dipersamakan dengan orang-orang Indonesia, maka kebiasaan bukanlah hukum kecuali jika Undang-Undang menentukannya.

Kalimat-kalimat tersebut bila dikaji jelas mencerminkan pemikiran hukum yang menjadi dasarnya, yaitu dinamakan hukum haruslah bentuknya tertulis. ${ }^{15}$

Dengan berdirinya Negara Republik Indonesia, kita mengenal adanya bermacammacam hukum, baik hukum tertulis yang merupakan peraturan-peraturan peninggalan zaman Hindia Belanda, maupun hukum tidak tertulis yang merupakan hukum adat yang beraneka ragam. Hanya saja permasalahan yang timbul saat ini, ketika kita melihat bahwa kecenderungan Indonesia yang mengikuti aliran Positivisme akan berpengaruh pada hukum adat yang merupakan hukum tidak tertulis yang diakui dan berkembang di lingkungan

\footnotetext{
${ }^{12}$ Maria Farida Indrati Soeprapto, op. cit., Hal. 4

${ }^{13}$ A. Hamid S. Attamimi, op., cit, Hal. 6

${ }^{14}$ Lili Rasjidi dan Ira Thania Rasjidi, Dasar-Dasar Filsafat dan Teori Hukum, Citra Aditya Bakti, Bandung: 2007, Hal. 56

${ }^{15}$ Lili Rasjidi dan Ira Thania Rasjidi, Ibid, Hal. 57
} 
masyarakat adat Indonesia. Dengan alasan tersebut di atas, maka penulis tertarik untuk mengangkat sebuah penelitian yang diberi judul "Korelasi Antara Hukum Adat Dengan Aliran Positivisme Di Indonesia"

Dari uraian latar belakang tersebut di atas, maka Penulis menyimpulkan rumusan masalah yang akan di bahas dalam penulisan ini adalah Bagaimanakah korelasi antara Hukum Adat dengan Aliran Positivisme di Indonesia?

\section{B. Metode Penelitian:}

Jenis penelitian atau pendekatan yang digunakan oleh penulis adalah penelitian hukum normatif yaitu penelitian hukum kepustakaan, karena menjadikan bahan kepustakaan sebagai tumpuan utama. Dalam penelitian hukum normatif ini penulis melakukan penelitian terhadap asas-asas hukum yang bertitik tolak dari bidang-bidang tata hukum tertentu, dengan cara mengadakan identifikasi terlebih dahulu terhadap kaidah-kaidah hukum yang telah dirumuskan di dalam perundang-undangan tertentu.

Sebagai pendukung, penelitian ini juga menggunakan pendakatan empiris yaitu mendapatkan informasi yang akurat dengan cara mengadakan identifikasi hukum dan bagaimana efektifitas hukum itu berlaku dalam masyarakat.

Dalam konsep normatif, hukum adalah norma, baik yang diidentikkan dengan keadilan yang harus diwujudkan (ius constituendum) ataupun norma yang telah terwujud sebagai perintah yang eksplisit dan yang secara positif telah terumus jelas (ius constitutum) untuk menjamin kepastiannya, dan juga berupa norma-norma yang merupakan produk dari seorang hakim (judgements) pada waktu hakim memutuskan suatu perkara dengan memperhatikan terwujudnya kemanfaatan dan kemaslahatan bagi para pihak yang berperkara. Sedangkan dilihat dari sifatnya penelitian ini bersifat deskriptif analisis.

Dalam penelitian ini analisis yang dilakukan adalah analisis kualitatif merupakan tata cara penelitian yang menghasilkan data deskriptif, yaitu apa yang dinyatakan secara tertulis. ${ }^{16}$ Selanjutnya, penulis menarik suatu kesimpulan secara deduktif, yaitu menarik kesimpulan dari hal-hal yang bersifat umum kepada hal-hal yang bersifat khusus. Dimana dalam mendapatkan suatu kesimpulan dimulai dengan melihat faktor-faktor yang nyata dan diakhiri dengan penarikan suatu kesimpulan yang juga merupakan fakta dimana kedua fakta tersebut dijembatani oleh teori-teori. ${ }^{17}$

\footnotetext{
${ }^{16}$ Soerjono Soekanto, Pengantar Penelitian Hukum, UII Press, Jakarta:1983, hlm 32.

${ }^{17}$ Aslim Rasyad, Metode Ilmiah; Persiapan Bagi Peneliti, UNRI Press, Pekanbaru: 2005, hal. 20.
} 


\section{Hasil dan Pembahasan}

\section{Hukum Adat}

Di dalam kehidupan masyarakat, selalu terdapat berbagai macam norma yang secara langsung atau tidak langsung mempengaruhi tata cara kita berperilaku atau bertindak. Di negara kita, norma-norma yang masih sangat dirasakan adalah norma-norma adat, normanorma agama, norma-norma moral, dan norma-norma hukum negara. Oleh karena negara kita terdiri atas berbagai-bagai pulau dan suku bangsa, serta ada kemerdekaan tiap-tiap penduduk untuk memeluk agamanya masing-masing dan untuk beribadat menurut agama dan kepercayaannya, maka norma-norma moral, norma-norma adat, dan norma-norma agama yang ada dan berlaku juga berbeda-beda satu dengan lainnya.

Norma adalah suatu ukuran yang harus dipatuhi oleh seseorang dalam hubungannya dengan sesamanya ataupun dengan lingkungannya. Suatu norma itu baru ada apabila terdapat lebih dari satu orang, karena norma itu pada dasarnya mengatur tata cara bertingkah laku seseorang terhadap orang lain, atau terhadap lingkungannya. Norma hukum itu dapat dibentuk secara tertulis ataupun tidak tertulis oleh lembaga-lembaga yang berwenang membentuknya, sedangkan norma-norma moral, adat, agama, dan lainnya terjadi secara tidak tertulis, tumbuh dan berkembang dari kebiasaan-kebiasaan yang ada dalam masyarakat. ${ }^{18}$

Untuk timbulnya Hukum kebiasaan itu diperlukan syarat-syarat tertentu, yaitu harus ada perbuatan atau tindakan yang semacam dalam keadaan yang sama dan harus selalu diikuti umum dan harus ada keyakinan hukum daripada golongan orang-orang yang berkepentingan. ${ }^{19}$

Dilihat dari perkembangan hidup manusia, terjadinya hukum itu dimulai dari pribadi manusi yang diberi Tuhan akal pikiran dan perilaku. Perilaku yang terus-menerus dilakukan perorangan menimbulkan kebisaan pribadi. Apabila kebiasaan pribadi itu ditiru orang lain, maka ia akan menjadi kebiasaan orang lain itu. Lambat laun dimasyarakat akan ikut pula melaksanakan kebiasaan itu. Kemudian apabila seluruh anggota masyarakat melakukan kebiasaan tadi, maka lambat laun kebiasaan tersebut menjadi adat dari masyarakat itu. Jadi adat adalah kebiasaan masyarakat, dan kelompok-kelompok masyarakat lambat laun menjadikan adat itu sebagai adat yang seharusnya berlaku bagi semua anggota masyarakat

\footnotetext{
${ }^{18}$ Maria Farida Indrati Soeprapto, op., cit, Hal. 6

${ }^{19}$ Hartono Hadisoeprapto, Pengantar Tata Hukum Indonesia, Liberty, Yogyakarta: 1981, Hal. 20-21
} 
dengan dilengkapi dengan sistem sanksi, sehingga menjadi hukum adat. Jadi, hukum adat adalah adat yang diterima dan harus dilaksanakan dalam masyarakat yang bersangkutan. Untuk mempertahankan pelaksanaan hukum adat itu agar tidak terjadi penyimpangan atau pelanggaran, maka diantara anggota masyarakat ada yang diserahi tugas mengawasinya. Dengan demikian lambat laun petugas-petugas adat ini menjadi kepala adat. ${ }^{20}$

Adat dan hukum adat kemudian secara historis-filosofis dianggap sebagai perwujudan atau pencerminan kepribadian suatu bangsa dan merupakan penjelmaan dari jiwa bangsa (volkgeist) suatu masyarakat negara yang bersangkutan dari zaman ke zaman. Oleh karena itu, setiap bangsa yang ada di dunia memiliki adat (kebiasaan) sendiri-sendiri yang satu dengan yang lainnya tidaklah sma. Dengan adanya ketidaksamaan tersebut, kita dapat mengetahui bahwa adat (kebiasaan) merupakan unsur yang terpenting dan memberikan identitas kepada bangsa yang bersangkutan di samping bangsa lainnya yang ada di dunia.

Tingkatan peradaban maupun cara hidup yang modern ternyata tidak dapat atau tidak mampu begitu saja menghilangkan adat (kebiasaan) yang hidup didalam peri kehidupan masyarakat, kalaupun ada yang terlihat dalam proses kemajuan zaman adalah adat (kebiasaan) tersebut selalu dapat menerima dan menyesuaikan diri dengan keadaan dan kehendak zaman sehingga oleh karenanya adat (kebiasaan) itu tetap kekal dan tetap segar dalam keadaan dan keberadaannya.

Didalam kehidupan masyarakat Indonesia adat yang dimiliki oleh suka bangsa berbeda-beda satu sama lainnya meskipun dasar dan sifatnya adalah satu yaitu keIndonesiaannya. Oleh karena itu, adat (kebiasaan) Bangsa Indonesia merupakan suatu Bhineka (berbeda-beda di daerah dan suku yang ada) akan tetapi Tunggal Ika (tetap satu jua) yaitu dasar dan sifat ke-Indonesiaannya. Adat Bangsa Indonesia yang Bangsa Indonesia yang Bhineka Tunggal Ika ini tidak bersifat statis namun selalu berkembang serta senantiasa bergerak berdasarkan keharusan tuntutan evolusi mengikuti proses perkembangan peradaban yang ada di dunia.

Adat (kebiasaan) istiadat yang hidup serta yang berkembang tersebut merupakan sumber bagi hukum adat sebagai hukum asli dari masyarakat dan Bangsa indonesia dimanapun dan sampai kapanpun.

Dalam perkembangannya istilah hukum adat tidak saja mengandung arti hukum kebiasaan yang tradisional, yang juga disebut hukum adat (dalam arti sempit) tetapi juga

\footnotetext{
${ }^{20}$ Tolib Setiady, Intisari hukum adat Indonesia, Alfabeta, Bandung: 2008, Hal. 1
} 
termasuk hukum kebiasaan yang modern. ${ }^{21}$ Pada umumnya hukum adat (dalam arti luas) tidak tertulis dalam bentuk perundangan dan tidak dikodifikasi, jadi tidak tersusun secara sistematis dan tidak dihimpun dalam bentuk kitab perundangan. Bentuk hukum adat tidak teratur, keputusannya tidak memakai konsideran, pasal-pasal aturannya tidak sistematis dan tidak mempunyai penjelasan, bahkan kebanyakan tidak tertulis atau dicatat.

Antara hukum di satu pihak dengan nilai-nilai sosial budaya di lain pihak terdapat kaitan yang erat. Hal ini telah dibuktikan berkat penyelidikan beberapa ahli antropologi hukum, baik bersifat perintis seperti Sir Henry Maine, A.M Post dan Yosef Kohler maupun Malinowski ${ }^{22}$ dan R.H. Lowie ${ }^{23}$ Kaitan yang erat antara hukum dan nilai-nilai sosial budaya masyarakat itu ternyata bahwa hukum yang baik tidak lain adalah hukum yang mencerminkan nilai-nilai yang hidup dalam masyarakat. ${ }^{24}$

Indonesia masa kini berada dalam masa transisi, yaitu sedang terjadi perubahan nilainilai dalam masyarakat dari nilai-nilai yang bersifat tradisional ke nilai-nilai yang modern. ${ }^{25}$ Namun masih menjadi persoalan nilai-nilai manakah yang hendak ditinggalkan dan nilai-nilai baru mana yang akan menggantikannya. Sudah barang tentu dalam proses perubahan ini akan banyak dihadapi hambatan-hambatan yang kadang-kadang akan menimbulkan keresahankeresahan maupun kegoncangan di dalam masyarakat.

Hukum adat adalah aturan kebiasaan manusia dalam hidup bermasyarakat. Perilaku yang terus menerus dilakukan perorangan menimbulkan "kebiasaan pribadi". Apabila kebiasaan pribadi itu ditiru orang lain, maka ia akan juga menjadi kebiasaan orang itu. Kemudian apabila seluruh anggota masyarakat melakukan perilaku kebiasaan tadi, maka lambat laun kebiasaan itu menjadi "adat" dari masyarakat itu. Jadi, adat adalah kebiasaan masyarakat, dan kelompok-kelompok masyarakat lambat laun menjadikan adat itu sebagai adat yang seharusnya berlaku bagi semua anggota masyarakat, sehingga menjadi "hukum adat”. Dan Hukum Adat adalah adat yang diterima dan harus dilaksanakan dalam masyarakat

\footnotetext{
${ }^{21}$ Hilman Hadikusuma, Bahasa Hukum Indonesia, Alumni, Bandung: 1992, Hal 31

${ }^{22}$ Lihat bukunya : Crime and Custom in Savage Society, 1926

${ }^{23}$ Lihat artikelnya: Anthropology and Law dalam The Social Sciences, 1927 dan Incorporated and Law dalam The Social-Sciences, 1927 dan Incorporated Property in Primitive Society dalam Yale Law Journal, 1928.

${ }^{24}$ Mochtar Kusumaatmadja: Fungsi dan Perkembangan Hukum dalam Pembangunan Nasional, Binacipta, Hal. 8. Lihat juga Soejono Soekanto: Pengantar Sosiologi Hukum, Bhratara Karya Aksara, 1977, Hal. 20. Perhatikan: Cairns. Hukum dan Ilmu-Ilmu Sosial Budaya (keduanya terjemahan) pada bagian lain buku ini Hal. 113. Dalam Lili Rasjidi dan Ira Thania Rasjidi, op.,cit, Hal. 80

${ }^{25}$ Soerjono Soekanto, Pengantar Sosiologi Hukum, Bhratara Karya Aksara, Jakarta, 1977, Hal. 19
} 
bersangkutan. ${ }^{26}$ Karena kebiasaan-kebiasaan yang dilakukan itu telah menjadi budaya dalam masyarakat.

Pada Hakekatnya kebudayaan itu memiliki tiga perwujudan yaitu pertama wujud kebudayaan sebagai suatu kompleks dari ide-ide, gagasan, nilai-nilai, norma-norma peraturan dan sebagainya. Kedua, kebudayaan dapat mewujudkan diri sebagai suatu kompleks aktifitas kelakuan berpola dari manusia dalam masyarakat. Dan ketiga, kebudayaan dapat berwujud sebagai benda-benda hasil karya manusia. Dengan bertitik tolak dari pengertian kebudayaan tersebut, maka dapat disimpulkan hukum adat salah satu perwujudan dari kebudayaan. ${ }^{27}$ Maka dapat disimpulkan kebiasaan menjadi kebudayaan, lalu kebudayaan menjadi hukum adat.

Mengingat Indonesia terdiri atas berbagai golongan suku bangsa dan memiliki beragam kebudayaan, tentunya kebiasaan yang ada di dalam setiap perbuatan hukum yang dilakukan dalam lingkungan masyarakat adat akan berbeda satu dengan lainnya, dan penggunaaan istilah adat dalam arti kebiasaan dilingkungan masyarakat sangat menonjol dari istilah lainnya. ${ }^{28}$ Hukum adat inilah yang tetap tumbuh dan berkembang dalam lingkungan masyarakat adat serta dipatuhi dan diwarisi ke penerus anak cucu yang tersebar di seluruh wilayah negara Indonesia.

\section{Hukum Positif}

Positivisme merupakan paham yang menuntut agar setiap metodologi yang dipikirkan untuk menemukan kebenaran hendaklah memperlakukan realitas sebagai sesuatu yang eksis, sebagai sesuatu objek, yang harus dilepaskan dari sembarang macam pra-konsepsi metafisis yang subjektif sifatnya. ${ }^{29}$ Yakni sebuah mahzab filsafat yang memiliki orientasi ilmiah pada warsa 30-an dan 40-an. Tujuannya adalah untuk menggusur sebagian besar filsafat dan agama sebagai sesuatu yang tidak bermakna dengan menetapkan kriteria verifikasi, dan untuk menegaskan kembali serta menyelesaikan persoalan-persoalan yang tersisa dengan

\footnotetext{
${ }^{26}$ Hilman Hadikusuma, Pengantar Ilmu Hukum Adat Indonesia, Mandar Maju, Bandung: 2003, Hal. 1

${ }^{27}$ I Gusti Ketut Sutha, Bunga Rampai Beberapa Aspekta Hukum Adat, Liberty, Jogyakarta: 1987, Hal. 28

${ }_{28}$ Zulherman Idris, Hukum Adat dan Lembaga-Lembaganya Keberadaan dan Perubahannya, UIR-Press, Pekanbaru: 2005, Hal. 2

${ }^{29}$ Lihat: Gordon Scott, dalam The History and Philosophy of Social Science, Routledge, London, 1991, Hal. 301, yang diikuti oleh Soetandyo dalam bukunya Hukum; Paradigma, Metode dan Pilihan Masalah, Dalam Otje Salman dan Anthon F. Susanto, Teori Hukum, Refika Aditama, Bandung: 2009, Hal. 79-80
} 
menggunakan bahasa formal yang ketat. Jadi "Tuhan ada" dan "Tuhan tidak ada" samasama tak bermakna karena tidak dapat diverifikasi. ${ }^{30}$

Positivisme hukum adalah bagian yang tidak dapat dilepaskan dari pengaruh perkembangan positivisme (ilmu). Dalam definisinya yang paling tradisional tentang hakikat hukum, dimaknai sebagai norma-norma positif dalam sistem perundang-undangan. ${ }^{31}$ Dari segi ontologinya, pemaknaan tersebut mencerminkan penggabungan antara idealisme dan materialisme. Oleh Bernard Sidharta dikatakan, penjelasan seperti itu mengacu pada teori hukum kehendak (the will theors of law) dari Jhon Austin dan teori hukum murni Hans Kelsen. Berbeda dengan pemikiran hukum kodrat yang sibuk dengan permasalahan validasi hukum buatan manusia, maka pada positivisme hukum, aktivitasnya justru diturunkan kepada permasalahan konkret . masalah validitas (legitimasi) aturan tetap diberi perhatian, tetapi standar regulasi yang dijadikan acuannya adalah norma-norma hukum. ${ }^{32}$

Menurut E. Sumaryono, positivisme hukum paling tidak dapat dimaknai sebagai berikut:

a. Aliran pemikiran dalam yurisprudensi yang membahas konsep hukum secara eklusif, dan berakar pada peraturan perundang-undangan yang sedang berlaku saat ini.

b. Sebagai sebuah teori yang menyatakan bahwa hukum hanya akan valid jika berbentuk norma-norma yang dapat dipaksakan berlakunya dan ditetapkan oleh sebuah instrument didalam sebuah negara. ${ }^{33}$

Menurut Lili Rasyidi, prinsip-prinsip dasar positivime hukum adalah:

a. suatu tata hukum negara berlaku bukan karena mempunyai dasar dalam kehidupan sosial (menurut Comte dan Spenser), bukan juga karena bersumber

\footnotetext{
${ }^{30}$ Anthon F. Susanto, Ilmu Hukum Non Sistematik Fondasi Filsafat Pengembangan Ilmu Hukum Indonesia, Genta Publishing, Yogyakarta, 2010, Hal. xiii

${ }^{31}$ Darji Darmodihardjo dan Sidharta berpendapat, positivisme hukum (aliran hukum positif) memandang perlu memisahkan secara tegas antara hukum dan moral (antara hukum yang berlaku dan hukum yang seharusnya, antara das sein dan das sollen), Lihat Darji Darmodihardjo dan Sidharta, Pokok-Pokok Filsafat Hukum: Apa dan Bagaimana Filsafat Hukum Indonesia, Gramedia, Jakarta, 2004, Hal. 113. Pengertian lain misalnya dapat dijelaskan sebagai berikut: positivisme hukum adalah aliran pemikiran yang dalam yurisprudensi yang membahas konsep hukum secara ekslusif. Kata ekslusif diturunkan dalam bahasa Latin exclusivus yang artinya tidak menampung atau memuat hal lain. Jika hukum dan moralitas memiliki otonomi yang ekslusif berarti masing-masing memiliki ruang lingkupnya sendiri-sendiri, dan masing-masing tidak berhubungan satu sama lain. Lihat E. Sumaryono, Etika Hukum, Relevansi Teori Hukum Kodrat Thomas Aquinas, Kanisius, Yogyakarta, 2002, Hal. 183. Dalam Anthon F. Susanto, Ibid, Hal. 70

${ }^{32}$ Anthon F. Susanto, Ilmu hukum Non Sistemik Fondasi Filsafat Pengembangan Ilmu Hukum Indonesia, Genta Publishing, Yogyakarta, 2010, Hal.71

${ }^{33}$ Ibid, Hal. 71
} 
pada jiwa bangsa (menurut Savigny), dan juga bukan karena dasar-dasar hukum alam, melainkan karena mendapatkan bentuk positifnya dalam instansi yang berwenang.

b. Hukum harus dipandang semata-mata dalam bentuk fromalnya; bentuk hukum formal dipisahkan dari bentuk hukum material.

c. Isi hukum (material) diakui ada, tetapi bukan bahan ilmu hukum karena dapat merusak kebenaran ilmiah ilmu hukum. ${ }^{34}$

Seorang pengikut Positivisme, Hart mengemukakan berbagai arti dari positivisme tersebut sebagai berikut:

1. hukum adalah perintah

2. Analisis terhadap konsep-konsep hukum berbeda dengan studi sosiologis, histories dan penilaian kritis.

3. keputusan-keputusan dideduksi secara logis dari peraturan-peraturan yang sudah ada lebih dahulu, tanpa perlu merujuk kepada tujuan-tujuan sosial, kebijaksanaan dan moralitas.

4. Penghukuman secara moral tidak dapat ditegakkan dan dipertahankan oleh penalaran rasional, pembuktian atau pengujian

5. Hukum sebagaimana diundangkan, ditetapkan, positum, harus senantiasa dipisahkan dari hukum yang seharusnya diciptakan, yang diinginkan ${ }^{35}$.

Salah seorang pengikut positivisme Hukum john Austin, seorang ahli hukum Inggris yang terkenal dengan ajaran analytical Jurisprudence menyatakan bahwa satu-satunya sumber hukum adalah kekuasaan yang tertinggi dalam suatu negara. Sedangkan sumbersumber lain hanyalah sebagai sumber yang lebih rendah. Sumber hukum itu adalah pembuatnya lansung, yaitu pihak yang berdaulat atau badan perundang-undangan yang tertinggi dalam suatu negara, dan semua hukum dialirkan dari sumber yang sama. Hukum yang bersumber dari situ harus ditaati tanpa syarat, sekalipun jelas dirasakan tidak adil. ${ }^{36}$

Menurut Austin, hukum terlepas dari soal keadilan dan terlepas dari soal baik dan buruk. Karena itu, ilmu hukum tugasnya hanyalah menganalisis unsur-unsur yang secara nyata ada dalam sistem hukum modern. Ilmu hukum hanya berurusan dengan hukum positif,

\footnotetext{
${ }^{34}$ Ibid, Hal. 73

${ }^{35}$ Satjipto Raharjo II, Buku Materi Pokok Pengantar Ilmu Hukum Bagian IV, Karunika, Jakarta, 1985, hlm. 111

${ }^{36}$ Muhammad Siddiq Tgk. Armia, Perkembangan Pemikiran Teori Ilmu Hukum, Pradnya Paramita, Jakarta, 2008, hlm. 6
} 
yaitu hukum yang diterima tanpa memperhatikan kebaikan atau keburukannya. Hukum adalah perintah dari kekuasaan politik yang berdaulat dalam suatu negara. ${ }^{37}$

Austin juga menegaskan bahwa hukum dipisahkan dari keadilan dan hukum tidak didasarkan pada nilai-nilai yang baik atau buruk, tetapi lebih disarkan kepada kekuasaan dari kekuatan penguasa. Austin membagi hukum kedalam dua bagian, yaitu hukum yang dibuat oleh Tuhan, dan hukum yang dibuat oleh manusia. Kemudian hukum yang dibuat oleh manusia tersebut dibedakan lagi antara hukum yang sebenarnya dan hukum tidak sebenarnya. $^{38}$

Hukum yang sebenarnya terdiri atas hukum yang dibuat oleh penguasa bagi pengikutpengikutnya dan hukum yang disusun oleh individu-individu guna melaksanakan hak-hak yang diberikan kepadanya. Hukum yang sebenarnya mengandung empat unsur yaitu: perintah, sanksi, kewajiban dan kedaulatan. Sedangkan hukum yang tidak sebenarnya ialah bukan hukum yang merupakan hukum yang secara lansung berasal dari penguasa, tetapi peraturan-peraturan yang berasal dari perkumpulan-perkumpulan ataupun badan-badan tertentu. $^{39}$

Menurut Thomas Aquino, hukum positif dinamakan Undang-Undang Manusia (Menschelijke Wet) adalah hukum yang ada dan berlaku. Menurutnya, Undang-undang tersebut tidak didasarkan alam, akan tetapi didasarkan akal. Undang-undang tersebut harus mengabdi kepentingan umum karena undang-undang adalah suatu peraturan tertentu dari akal yang bertujuan untuk mengabdi kepentingan umum dan berasal dari satu "kekuasaan" yang sebagai penguasa tertinggi harus memelihara kesejahteraan masyarakat. Hukum positif aalah sesuatu yang perlu untuk umat manusia, hukum positif kebanyakan ditaati oleh manusia dengan sukarela dengan jalan peringatan-peringatan dan tidak oleh karena paksaan oleh undang-undang.

Kelsen mengatakan, jika hukum telah menentukan pola perilaku tertentu, maka tiap orang seharusnya berperilaku sesuai pola yang ditentukan itu. Singkatnya, "orang harus menyesuaikan diri dengan apa yang telah ditentukan". Di sinilah letak sifat normatif dari hukum. Keharusan dan kewajiban menaati hukum, melulu karena telah ditentukan demikian (secara yuridis-formal), bukan karena nilai yang dikandung dalam materi hukum itu sendiri. Dari sinilah kita kenal term "yuridis-normatif". ${ }^{40}$ Sumber semua itu adalah dari Grundnorm

\footnotetext{
${ }^{37}$ Ibid

${ }^{38}$ Sabian Usman, Dasar-Dasar Sosiologi Hukum, Pustaka Belajar, Yogyakarta, 2009 hlm. 149

${ }^{39}$ Ibid, hlm. 149-150

${ }^{40}$ Satjipto Rahardjo, op., cit, Hal: 127
} 
(norma dasar). Grundnorm menyerupai sebuah pengandaian tentang "tatanan" yang hendak diwujudkan dalam hidup bersama (dalam hal ini, negara). Kelsen sendiri tidak menyebut isi dari grundnorm tersebut. Ia hanya katakan, grundnorm merupakan syarat transedental-logis bagi berlakunya seluruh tata hukum. Seluruh tata hukum positif harus berpedoman secara hirarki pada grundnorm. Dengan demikian, secara tidak langsung, Kelsen juga sebenarnya membuat teori tentang tertib Yuridis. ${ }^{41}$

Norma dasar hukum tidak dapat di samakan dengan suatu hukum alam, yakni suatu hukum yang melekat pada hal-hal. Kelsen sama sekali menolak suatu kewajiban hukum yang berasal dari keadaan hal sendiri. Menurut Kelsen satu-satunya hukum adalah hukum positif ; hukum lain tidak ada. Orang-orang yang hidup bersama membentuk hukum guna mengatur hidup bersama itu. Dalam hal ini Kelsen memang konsekuen. Bagi dia seluruh hukum terkandung dalam perumusan, yang menggabungkan dua kenyataan tertentu menurut prinsip tanggungan. Dari pihak pribadi terdapat tindakan yang melawan hukum, dari pihak kekuasaan tindakan balasan menyusul. Jadi hukum tidak ada hubungan dengan suatu subyek yang mempunyai suatu hak. Hak dan kewajiban dalam bidang hukum hanya ada kalau ditentukan hukum positif. Berdasarkan dari pandangan ini Kelsen dapat mengatakan, bahwa binatang dan bunga memiliki hak yang sama kuat dengan manusia, yakni tidak memiliki hak apa pun, tetapi baik binatang maupun bunga dapat dilindungi oleh hukum positif, dan hukum lain tidak ada. Hal ini berarti pula, bahwa norma-norma yang tidak ditaati lagi tidak berlaku. Kalau dirumuskan suatu norma hukum, memang diandaikan bahwa pernah terdapat suatu pelanggaran. Kalau tidak, norma hukum itu bertepatan dengan keadaan yang sebenarnya dan tidak usah dibentuk suatu norma. Tetapi kalau pelanggaran-pelanggaran sudah begitu banyak sehingga dapat dikatakan bahwa efektivitas norma itu hilang, maka norma itu kehilangan berlakunya. ${ }^{42}$ Begitulah teori dari Hans Kelsen yang menyatakan bahwa hukum itu normatif karena Grundnorm.

\section{Hukum Adat Dalam Teori Positivisme}

Menurut seminar hukum adat dan pembinaan hukum nasional pada tanggal 15-17 Januari 1975 di Yogyakarta, hukum adat diartikan hukum Indonesia asli yang tidak tertulis dalam bentuk perundang-undangan Republik Indonesia asli yang tidak tertulis dalam bentuk perundang-undangan Republik Indonesia yang di sana sini mengandung unsur agama.

\footnotetext{
${ }^{41} \mathrm{Ibid}$.

${ }^{42}$ Theo Huijbers, op, cit., Hal. 158-159
} 
Tentang istilah Indonesia asli menurut Prof. Iman Sudiyat SH pada penataran hukum adat di Aceh tahun 1981, dikatakan yang benar bukan Hukum Indonesia Asli tetapi Hukum Asli Indonesia. Jadi yang dimaksud dengan istilah hukum adat adalah hukum yang tidak tertulis dalam bentuk perundangan negara, termasuk pula hukum kebiasaan. ${ }^{43}$

Hukum, apabila dibedakan menurut sumbernya adalah $:{ }^{44}$

a. Hukum undang-undang, yaitu hukum yang tercantum dalam peraturan perundangan;

b. Hukum kebiasaan (adat), yaitu hukum yang terletak di dalam peraturan-peraturan kebiasaan (adat);

c. Hukum traktat, yaitu hukum yang ditetapkan oleh negara-negara di dalam suatu perjanjian antara negara (traktat);

d. Hukum jurisprudensi, yaitu hukum yang terbentuk karena keputusan hakim.

Meskipun di seluruh Indonesia berlaku satu hukum adat, tetapi hukum adat itu sendiri tidak merupakan satu kesatuan. Tiap-tiap suku bangsa mempunyai hukum adat masingmasing. ${ }^{45}$ Menurut isinya, hukum adat mempunyai 4 macam unsur, yaitu:

1. Hukum tidak tertulis (kebiasaan asli);

2. Hukum tertulis (dibentuk oleh pembentuk hukum asli);

3. Hukum yang berasal dari agama;

4. Hukum berasal dari luar

Di dalam hukum adat tidak terdapat pemisahan yang prinsipil antara hukum sipil dan hukum publik. Ini disebabkan karena susunan masyarakat Indonesia mengandung siat-sifat religius dan mistis. Penyelenggaraan dan pemeliharaan hukum adat, dilaksanakan di dalam suatu masyarakat hukum, khususnya yang berada di desa dan daerah pedalaman yang masih kental dengan adat istiadat dan budaya nenek moyang nya.

Sejauh hemat Penulis, melihat sudut pandang teori Hans Kelsen maka Mazhab Positivisme tidak dapat di berlakukan di Negara Indonesia, karena Negara Indonesia sendiri yang terdiri dari beribu-ribu pulau dan beragam suku bangsa, ras, dan agama yang kaya dengan keanekaragaman budaya dan adat yang masih tumbuh dan berkembang dilingkungan masyarakat. Hal ini disebabkan, para leluhur atau nenek moyang yang akan terus mewarisi hukum adat yang berlaku tersebut kepada anak cucunya. Yang mana, hukum adat itu tidak

\footnotetext{
${ }^{43}$ Hilman Hadikusuma, op, cit, Hal. 31

${ }^{44}$ Cansil, Pengantar Ilmu Hukum dan Tata Hukum Indonesia, Balai Pustaka, Jakarta: 1983, Hal. 71

${ }^{45}$ Wiratmo, Pengantar Tata Hukum Indonesia, Perpustakaan Fakultas Universitas Islam Indonesia, Yogyakarta: 1988, Hal. 85
} 
dirangkum, ditulis ataupun dikodifikasi selayaknya hukum positif. Tetapi ruh dari hukum adat itu akan terus melekat dan tidak akan punah dalam masyarakat adat.

Untuk menjadikan hukum adat itu tertulis sangatlah tidak mungkin, karena adat yang tersebar di seluruh Negara Kesatuan Republik Indonesia, berbeda-beda di tiap daerahnya dan sangatlah banyak jumlahnya. Kita belum dapat menentukan hukum adat mana yang mampu menjadi pedoman bagi hukum-hukum adat yang ada di Indonesia, karena jika kita pilih salah satu hukum adat tersebut maka akan terjadi tumpang tindih antara hukum adat yang satu dengan hukum adat lainnya. Seperti contoh, mengenai hukum waris di Minangkabau yang menggunakan sistem Matriliakat (sistem keturunan Ibu) akan berbeda dengan hukum waris di adat Melayu yang menggunakan sistem Patriliakat (sistem keturunan Ayah).

Sementara teori Positivisme Hans Kelsen yang menyatakan bahwa hukum itu adalah hukum positif yakni hukum yang tertulis, jika kita menggunakan teori ini di Indonesia maka Hukum Adat yang tidak tertulis itu tidak dapat di berlakukan walaupun dalam masyarakat adat, dengan artian bahwa seluruh masyarakat yang ada di wilayah Kesatuan Republik Indonesia hanya harus menaati hukum yang tertulis saja, jadi hukum yang tidak tertulis bukanlah hukum yang harus ditaati.

Hal ini akan menimbulkan pengaruh yang tidak baik dalam keyakinan masyarakat adat yang telah lama percaya dan mematuhi hukum adat yang di warisi oleh Para Leluhurnya. Tentunya akan menimbulkan suatu pertentangan antara masyarakat adat dengan aparat Pemerintah. Melihat dari pertentangan teori tersebut mengenai kedudukan hukum adat yang tidak diakui dikarenakan tidak bersifat tertulis. Jadi, sudah semestinya Indonesia tidak cenderung mengikuti aliran positivisme dari Hans Kelsen.

Hanya saja, peraturan-peraturan yang ada (hukum positif) dengan peraturan-peraturan yang diharapkan ada, hendaklah melihat dari aspek sosiologis yang terjadi di tengah masyarakat adat. Dalam artian, hukum tidak terlepas dari kebudayaan. Karena hukum sebagai salah satu manifestasi dari pada kebudayaan itu pun juga merupakan suatu proses, apabila hukum itu hendak dikatakan hidup. ${ }^{46}$ Sebagai suatu manifestasi daripada kebudayaan itu, maka hukum itu juga merupakan lembaga kemasyarakatan, sebab hukum adalah suatu cara untuk memenuhi kebutuhan manusia dalam hidup kemasyarakatannya.

\section{Kesimpulan}

\footnotetext{
${ }^{46}$ Sunarjati Hartono, Dari Hukum Antar Golongan ke Hukum Antar Adat, Alumni, Bandung: 1986, Hal. 9
} 
Dalam paradigma postivisme sistem hukum tidak diadakan untuk memberikan keadilan bagi masyarakat, melainkan sekedar melindungi kemerdekaan individu (person). Kemerdekaan individu tersebut senjata utamanya adalah kepastian hukum. Paradigma positivime berpandangan demi kepastian, maka keadilan dan kemanfaatan boleh diabaikan. Pandangan positivistik juga telah mereduksi hukum dalam kenyataannya sebagai pranata pengaturan yang kompleks menjadi sesuatu yang sederhana, linear, mekanistik dan deterministik. Hukum tidak lagi dilihat sebagai pranata manusia, melainkan hanya sekedar media profesi. Akan tetapi karena sifatnya yang deterministik, aliran ini memberikan suatu jaminan kepastian hukum yang sangat tinggi. Artinya masyarakat dapat hidup dengan suatu acuan yang jelas dan ketaatan hukum demi tertib masyarakat merupakan suatu keharusan dalam positivisme hukum.

Aliran positivisme banyak menuai kritik dari para ahli hukum. Tujuan dari positivisme hukum adalah kepastian hukum. Hukum terpisah dari norma-norma yang hidup didalam masyarakat karena yang dikatakan hukum adalah peraturan yang sah yang dikeluarkan oleh penguasa. Sehingga terjadinya deviasi nilai-nilai keadilan, antara keadilan menurut hukum dan keadilan menurut masyarakat. Sejatinya hukum dan masyarakat adalah dua hal yang tidak dapat dipisahkan. Hukum harus bersumber dari norma-norma yang hidup dimasyarakat, karena tujuan hukum adalah untuk menciptakan ketertiban dan keadilan ditengah masyarakat.

Teori Positivisme dari Hans Kelsen tidak dapat diterapkan di Indonesia, karena masih tetap berlaku dan di akuinya hukum adat yang tidak tertulis di dalam masyarakat adat yang ada di Indonesia. Banyaknya suku bangsa, ras, agama, dan beraneka ragam adat serta budaya yang memiliki hukum adat yang berbeda pula, maka hukum adat di Indonesia tidak dapat dikodifikasi atau di buat secara tertulis. Hukum adat yang walau tidak terangkum dalam bentuk tertulis, tapi tetap harus di akui sebagai hukum yang ada di Indonesia, dan tidak boleh di hilangkan mengingat kedudukan hukum adat yang masih di akui, tumbuh dan berkembang dalam masyarakat adat.

Hukum positif di Indonesia ataupun hukum yang diharapkan hadir untuk kedepannya di Indonesia, haruslah melihat dari aspek kebudayaan atau hukum adat yang tumbuh dan berkembang di lingkungan masyarakat adat. Mengingat tujuan dari di bentuknya suatu peraturan atau hukum adalah untuk memenuhi kebutuhan manusia dalam hidup kemasyarakatannya. Jadi yang menikmati hukum adalah masyarakat. 


\section{Daftar Pustaka}

\section{Buku}

A. Ahsin Thohari, 2004, Komisi Yudisial dan Reformasi Keadilan, ELSAM, Jakarta.

Abdul Rasyid Thalib, 2006, Wewenang Mahkamah Konstitusi dan Implikasinya dalam Sistem Ketatanegaraan RI, Citra Aditya Bakti, Bandung.

Aslim Rasyad, 2005,Metode Ilmiah; Persiapan Bagi Peneliti, UNRI Press,Pekanbaru.

Bambang Sutiyoso, Sri Hastuti Puspitasari, 2003, Aspek-Aspek Perkembangan

Kekuasaan Kehakiman di Indonesia, PT. Citra Aditya Bakti, Bandung.

Burhan Ashshofa, 1996, Metode Penelitian Hukum, PT. Rineka Cipta, Jakarta.

Dahlan Thaib, Jazim Hamidi, Ni'matul Huda, 2006, Teori dan Hukum Konstitusi, PT. Raja Grafindo Persada, Jakarta.

Cansil, Pengantar Ilmu Hukum dan Tata Hukum Indonesia, Balai Pustaka, Jakarta: 1983

Hadikusuma, Hilman, Bahasa Hukum Indonesia, Alumni, Bandung: 1992

Hilman, Pengantar Ilmu Hukum Adat Indonesia, Mandar Maju, Bandung: 2003

Hadisoeprapto, Hartono, Pengantar Tata Hukum Indonesia, Liberty, Yogyakarta: 1981

Hartono, Sunarjati, Dari Hukum Antar Golongan ke Hukum Antar Adat, Alumni, Bandung: 1986

Huijbers, Theo, Filsafat Hukum Dalam Lintasan Sejarah, Kanisius, Yogyakarta: 1982

Ichlasul Amal, 2004, Sistem Pemerintahan RI, Jakarta: Lembaga Administrasi Negara.

Idris, Zulherman, Hukum Adat dan Lembaga-Lembaganya Keberadaan dan Perubahannya,

UIR-Press, Pekanbaru: 2005

Inu Kencana Syaiie, 2004, Sistem Pemerintahan Indonesia,Gema Insani Press,Jakarta.

Kelsen, Hans, Pengantar Teori Hukum, Nusamedia, Bandung: 2009

Kunthi Dyah Wardani, 2007, Impeachment dalam Ketatanegaraan Indonesia, UIIPress,

Yogyakarta

Mahfud MD, 2000, Demokrasi dan Konstitusi di Indonesia, Studi tentang Interaksi Politik

Kehidupan Ketatanegaraan, PT. Rineka Cipta, Jakarta.

Miriam Budiardjo, 1991, Dasar- Dasar Ilmu Politik, Gramedia, Jakarta.

Rahardjo, Satjipto, Teori Hukum, Genta Publishing, Yogyakarta: 2010

Rahimullah, 2007, Hubungan Antar Lembaganegara Versi Amandemen UUD1945, PT. Gramedia, Jakarta.

Rasjidi, Lili dan Ira Thania Rasjidi, Dasar-Dasar Filsafat dan Teori Hukum, Citra Aditya Bakti,

Bandung: 2007

Ridwan HR, 2006, Hukum Administrasi Negara, PT. Raja Grafindo Persada.

Sarwoto, 2000, Perbandingan Sistem pemerintahan,Galih Indonesia,Jakarta.

Sobirin Malian, 2001, Gagasan Perlunya Konstitusi Baru Pengganti UUD 1945, UII Press, Yogyakarta.

Soehino, 1985, Hukum Tata Negara, Sumber-sumber Hukum Tata Negara Indonesia, Liberty, Yogyakarta.

Soekanto, Soerjono, Pengantar Sosiologi Hukum, Bhratara Karya Aksara, Jakarta, 1977

Soeprapto, Maria Farida Indrati, Ilmu Perundang-Undangan, Kanisius, Yogyakarta: 1998 
Susanto, Anthon F., Ilmu Hukum Non Sistematik Fondasi Filsafat Pengembangan Ilmu Hukum Indonesia, Genta Publishing, Yogyakarta, 2010

Sutha, I Gusti Ketut, Bunga Rampai Beberapa Aspekta Hukum Adat, Liberty, Jogyakarta: 1987

Sri Soemantri, 1987, prosedur dan Sistem Perubahan Konstitusi, Disertasi, Alumni, Bandung. dalam Dahlan Thaib, Jazim Hamidi, Ni'matul Huda, 2008, Teori dan Hukum Konstitusi, PT. Raja Grafindo Persada, Jakarta.

Wiratmo, Pengantar Tata Hukum Indonesia, Perpustakaan Fakultas Universitas Islam Indonesia, Yogyakarta: 1988

\section{Makalah}

Attamimi, A. Hamid S. Fungsi Ilmu Perundang-Undangan dalam Pembentukan Hukum Nasional, makalah disampaikan pada ceramah ilmiah di fakultas Hukum Universitas Islam Assyafiah, Jakarta 17 Maret 1989

\section{Kamus:}

Departemen Pendidikan Nasional, 2003, Kamus Besar Bahasa Indonesia, Balai Pustaka, Jakarta

\section{Undang-undang}

Indonesia, Undang-Undang Dasar 1945, Pembukaan

\section{Internet:}

www.wikipediaindonesia.co.id. www.kompas. com. www.okezone.com. www.forum.detik.com. 